\title{
Assessment of China - Nigeria Trade Relations (1990-2018)
}

DOI: https://doi.org/10.47175/rissj.v1i1.4

\author{
| Opusunju, Michael Isaac ${ }^{1, *} \mid$ Akyuz, Murat ${ }^{2}$ | Inim, E. Victor ${ }^{3}$ |
}

${ }^{1}$ Departement of Business

Administration Nasarawa State

University, Keffi, Nigeria

${ }^{2}$ Deparment of Business

Administration Nile University of Nigeria, Abuja, Nigeria

${ }^{3}$ Deparment of Accounting Nile

University of Nigeria, Abuja,

Nigeria

1,*opusunjumike@gmail.com

${ }^{2}$ murat.akyuz@nileuniversity.edu.ng

${ }^{3}$ victor.inim@nileuniversity.edu.ng

\begin{abstract}
The study assessed China- Nigeria trade relations covering a period of 29 years from 1990 to 2018. The study adopted the ex-post facto research design and obtained data for export and import transactions from the Central Bank of Nigeria statistical bulletin. The study used T-test, charts, and tables to address the engagement of China-Nigeria trade relations. The study used Microsoft excel software package and statistical package for social sciences (SPSS) version 20 to analysis the data. The study found that Nigeria has not gained from trade relations with China from 1990 to 2018 and it is only China that benefited from trade relations with Nigeria from 1990 to 2018. The study recommended that the Nigerian Government should re-strategise its industrial sector to enable the country to manufacture industrial goods and manufactured consumable goods as well as medical equipment to export to China. They should try to discover what type of industrial goods that China does not well produce and should re-strategise to produce it with low labour and low capital. The Chinese Government should continue to import goods to Nigeria since they are the ones benefiting from trade relations in Nigeria from 1990 to 2018. They should also encourage the Nigerian government to produce and manufacture industrial goods so that they can face a little competitive with Nigeria in the future for improvement of their products.

KEYWORDS

Trade relations; import and export
\end{abstract}

\section{INTRODUCTION}

Chain - Nigeria trade relations commenced in Nigeria by 1971 but the first disagreement of this trade relations was in 1979 when the government of Nigeria disregarded China's support for the Union for the total independence of Angola (Ogunsanwo, 2008). This rebel was not in favour of Nigeria's support for the Popular Movement for the Liberation of Angola (MPLA) and surprisingly, this was political disagreement that failed to alter trade relations between the two countries (Ogunsanwo, 2008).

The Nigeria China trade relations are very relevant based on the fact Nigeria is a developing country while China is a developed country. Nigeria can learn trade ideas from China, which are the strategy to import goods that they have deficiencies in production (low labour and low capital) from China. Chinese government can also learn from Nigeria's government trade export, that is, what they have deficiencies in producing. Nigerian government can ascertain if they again from engaging in trade relations with the Chinese government or not. The idea of trade relations is both countries to gain from each other. For instance, Nigeria produces oil and gas with low labour and low capital as well as having available resources to utilize the production process. Also, Nigeria had difficulties in producing computers and its accessories using low labour and low capital as well as technological know-how. China produced computers and its accessories at low labour, low 
capital, and effective technological know-how. They are not blessed with many natural resources like oil and gas and agricultural outputs. Therefore trade relations benefit both countries and they gain from each other in the process of transacting businesses.

The major problem that the researchers are interested to unfold in this study is that Nigeria -China trade relations have existed for more than five (5) decades after Nigeria gain independence in 1961. Though trade was not fully implemented by these countries at that time since 1990, the trade relations between the two countries are stable. However, it is uncertain whether the Nigerian Government has gained from trade relations with the Chinese government and ascertained the position of Nigeria in engaging in trade relations.

The objective of this study is to assess the China-Nigeria trade relations from 1990-2018. The specific objectives of this study are to: ascertain whether Nigeria or China gain from trade relations in Nigeria and also determine the position of Nigeria in trade relations with China.

The scope of this study is restricted to the assessment of China - Nigeria trade relations from 1990 to 2018, 29 years. This period is chosen because Nigeria had its democratic era in 1990 and the country has enjoyed freedom in conducting business with the Chinese government. The period is also chosen because the Nigerian-Chinese Chamber of Commerce was founded in 1994 which also included in the period of study.

The hypotheses of this study are stated below:

$\mathrm{H}_{01}$ : Nigeria has not gained from Trade Relations with the Chinese Government from 1990 $-2018$

\section{China - Nigeria Trade Relations}

Nigeria - China trade relations Memorandum of understating was signed in 2016 which paved the way for strategic partnership and Nigeria was the first country in Africa to sign a trade pact with China (Taylor, 2007). The former president Dr. Olusegun Obasanjo encourage investors from China to transact business in Nigeria and ensure that was oil-for infrastructure deal which Chinese firms were offered right-first refusal for oil processing licenses (Obiorah, 2006, Taylor, 2007; Mthembu-Slater, 2009).

After investing US\$2 billion to build a falling oil refinery in Kaduna- Northern Nigeria and the China National Petroleum Corporation (CNPC) was giving an oil processing license which the contract later ended with resumption to the office by President Umaru Yar'Adua in 2007 (Mthembu-Salter, 2009). 2007 was the year China company introduced Nigeria's communication satellite that is called Nig Comsat which has 15 years lifespan. This was owned by Great Wall Industry Corporation at the Xixhang Satellite Launch Centre (Umejei, 2009).

Great Wall Industry Corporation was to be handed over to the government of Nigeria on May 13, 2009, based on the agreement but it was not handed over to the government in November 2008 which left cautious optimism in trade transactions between Nigeria and China (Ogunsanwo, 2008).

FOCAC stated in 2000 which mean Form on China-Africa Cooperation and the prompt actions of the Beijing Summit of FOCAC in 2006. It was noted trade between Nigeria and China was encouraging and they enjoyed speedy growth and development.

Former President Olusegun Obasanjo's election in 1999 coincided with the start of a new Chinese orientation toward Africa in 2000 and his second tenure in office (2003-2007). China's President, Hu Jintao and Prime Minister, Wen Jiabao came to Nigeria regarding trade relations while President Obasanjo visits Beijing two times to negotiate on trade relations. It was in 2001, that Nigeria built a trade office in China and China built an office called China Investment Development and Trade Promotion Centre in Nigeria. After 2002, 
the intergovernmental Nigeria-China Investment Forum was established in 2006 but it was in 2016 , both countries celebrated the $45^{\text {th }}$ anniversary of the trade relations and diplomatic ties between Nigeria and China.

\section{China - Nigeria Trade Model}

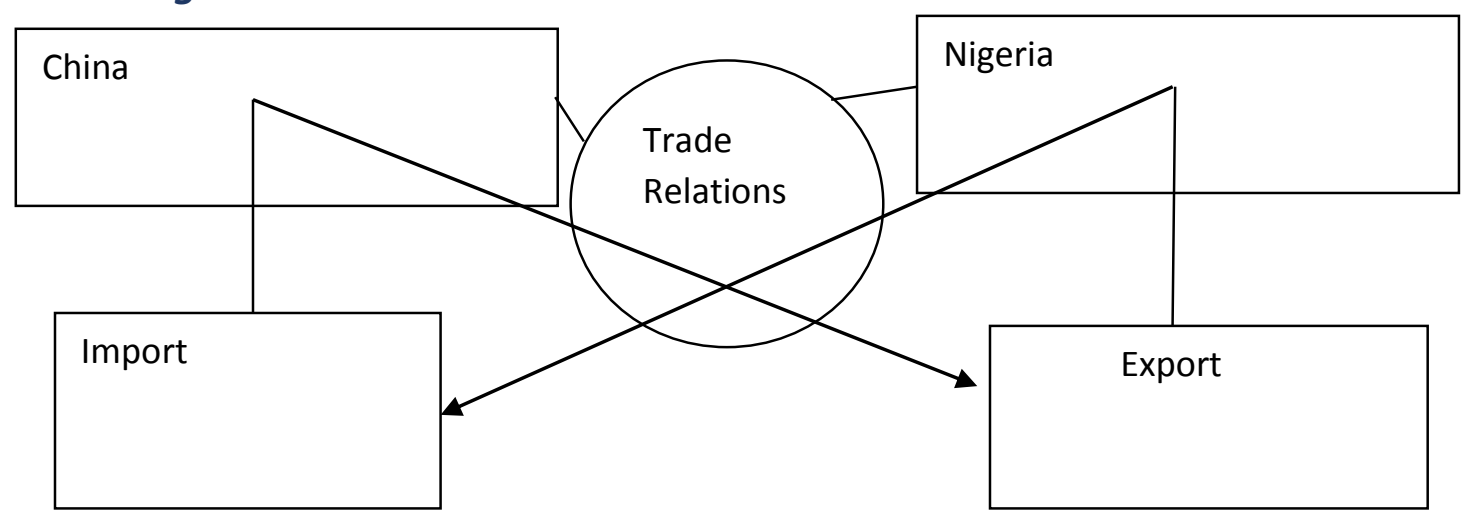

\section{METHODOLOGY}

Source: Researchers Model, 2019

The study adopted the ex-post facto research design. The study collected data on export and import for trade relations between Nigeria and China from the Central Bank of Nigeria statistical bulletin. Data collected from the Central bank of Nigeria is unique and authentic and reflects the position of involvement of China and Nigeria trade relations in Nigeria. The study used chart and a T-test to ascertain the assessment of trade relations between the two countries. The reason for using chart is to enable the researchers to compare the export trade of Nigeria to China and import trade of China to Nigeria. The t-test is used to determine if there is a significant difference between the means of two groups, which may be related to certain features such as export trade from Nigeria to China and Import trade from China to Nigeria. The study used e-view 9.00 to analysis the data.

\section{Data Analysis and Discussion}

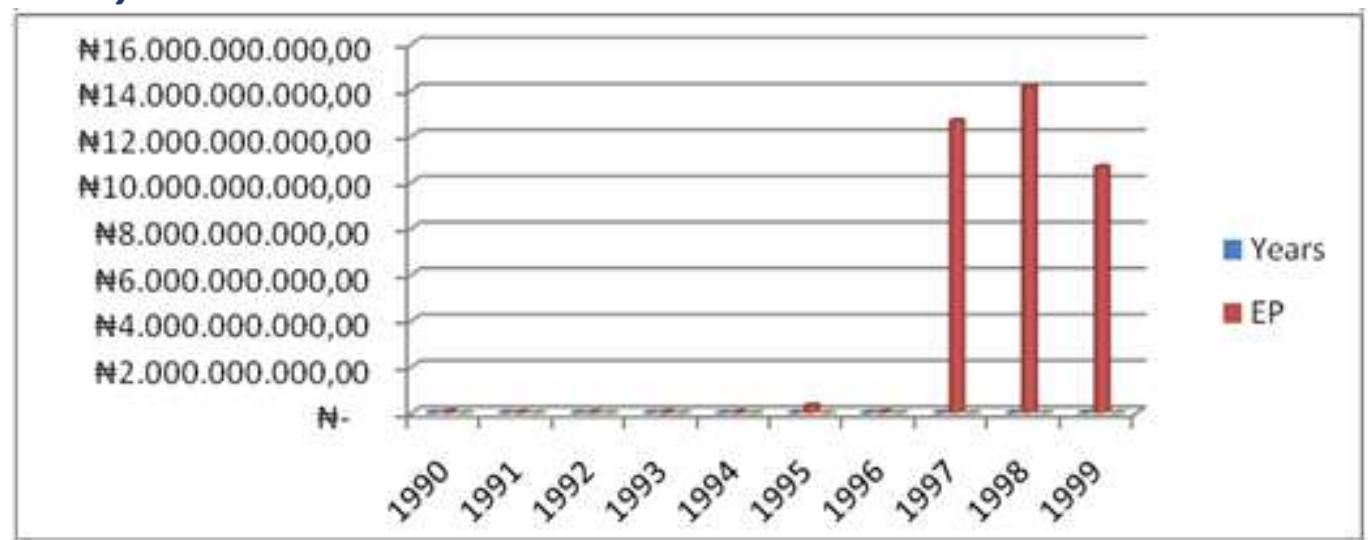

Figure 1. Export from Nigeria to China (1990-1999) Source: output from Excel, 2019

The figure above indicates the Export of Goods from Nigeria to China starting from 1990 to 1999 when Nigeria start a democratic era. From 1990 to 1996 which is six (6) years, Nigeria exports its products to China at a very little rate and amount. It was in 1997 that the export of Nigeria products into Chinese increase at about N12.3 billion. However, such an increase in the Export of Nigerian products was high which was obtained in 1998 than in 1997. The 1998 export trade from Nigeria to China recorded about N14 Billion but export 
trade in China dropped in 1999 when Nigeria had a democratic era. The start of democracy in Nigeria had a slowdown in the increase of export of Nigerian products to China. This chart implies that Nigeria export their products to China at a very little rate and even then there was an increased in export in 1997 and 1998, the start of democratically elected government recorded slowdown in the export of Nigerian products to China.

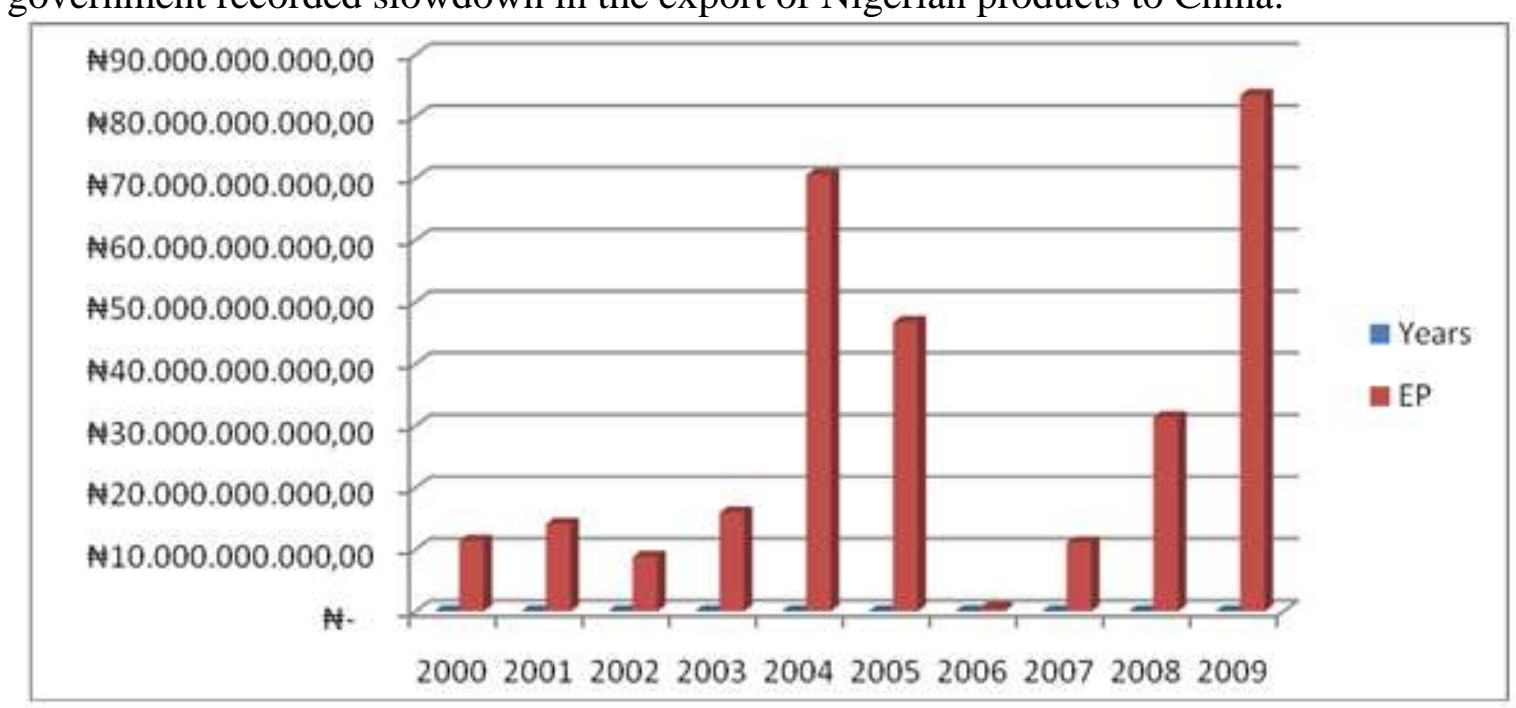

Figure 2. Export from Nigeria to China (2000-2009)

Source: output from Excel, 2019

The above figure revealed that Nigeria's engagement in trade relations with China is fluctuating since in 2000, Nigeria exports its products to China at a very little rate of about $10,000,000,000.00$ and Nigeria had a very little increased in the exportation of their products to China in 2001 at about 14,000,000,000.000. In 2002, the export of Nigerian products to China dropped and eventually rise at the very little rate in 2003. It was in 2004 that Nigeria recorded a high rate of export of its products to China but this rate did not last since the following year recorded a decrease in export of Nigeria products to China. The 2006 export of Nigeria products to China was very poor but in 2007 , there was a very little increase in Nigerian products export to China. However, 2008 recorded a very moderate increase in made in Nigeria products export to China and this increase in 2008 reflected in 2009 when Nigeria recorded a very high increase in export of goods to China. This chart implies that the export of goods from Nigeria to China is very little and fluctuating.

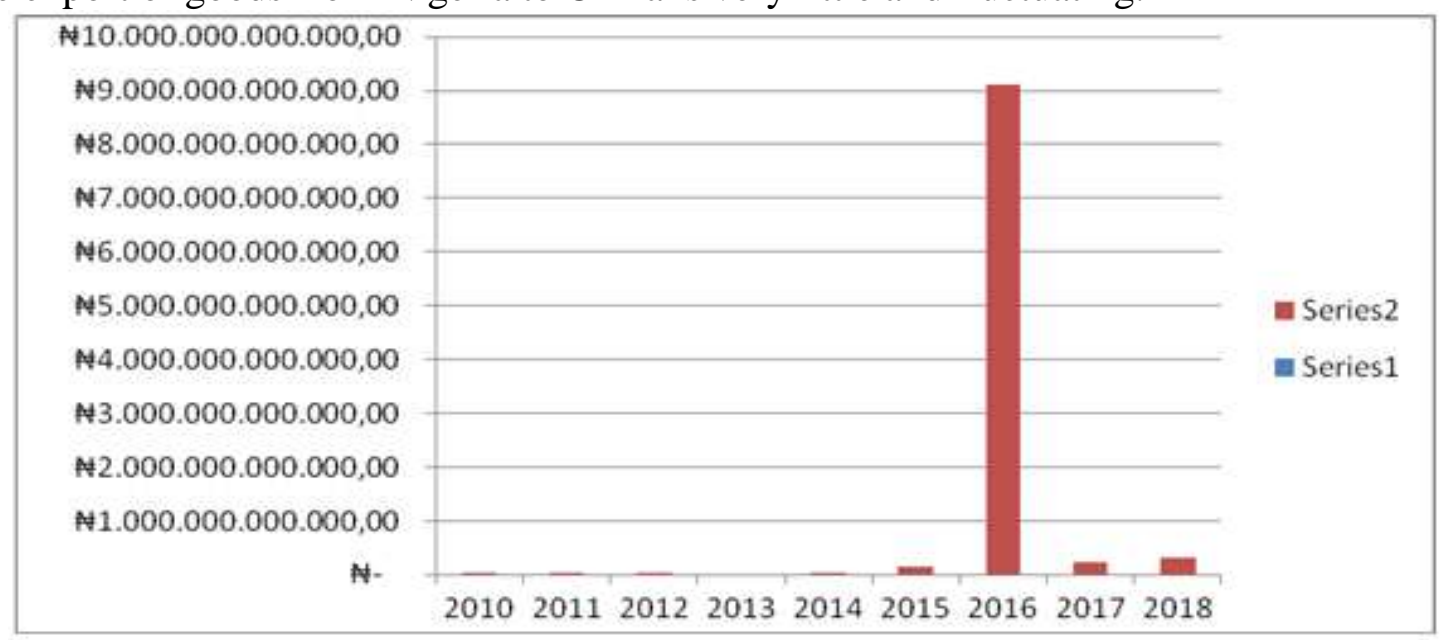

Figure 3. Export from Nigeria to China (2010-2018)

Source: output from Excel, 2019 
Figure The t recorded that Export of goods from Nigeria to China was very poor in 2010, 2011, 2012, 2013 and 2014 at these amount $110,804,260,000, N 1,706,576,000$, $\$ 1,674,434,000, \$ 1,537,958$ and $\$ 2,345,535$. It was in 2015 that the export of Nigerian products had very little increase at $157,485,113,315.90$. However, 2016 recorded a high

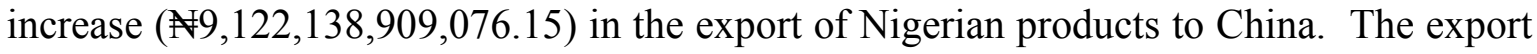
of goods from Nigeria to China in 2017 ( $220,569,168,578.98$ ) was very poor and just a little different at a similar rate was obtained in 2018 ( $\$ 315,033,538,329.91)$ which indicate that Nigeria export very little products to China. This chart implies that Nigeria's export of goods to China at a very little rate within these years.

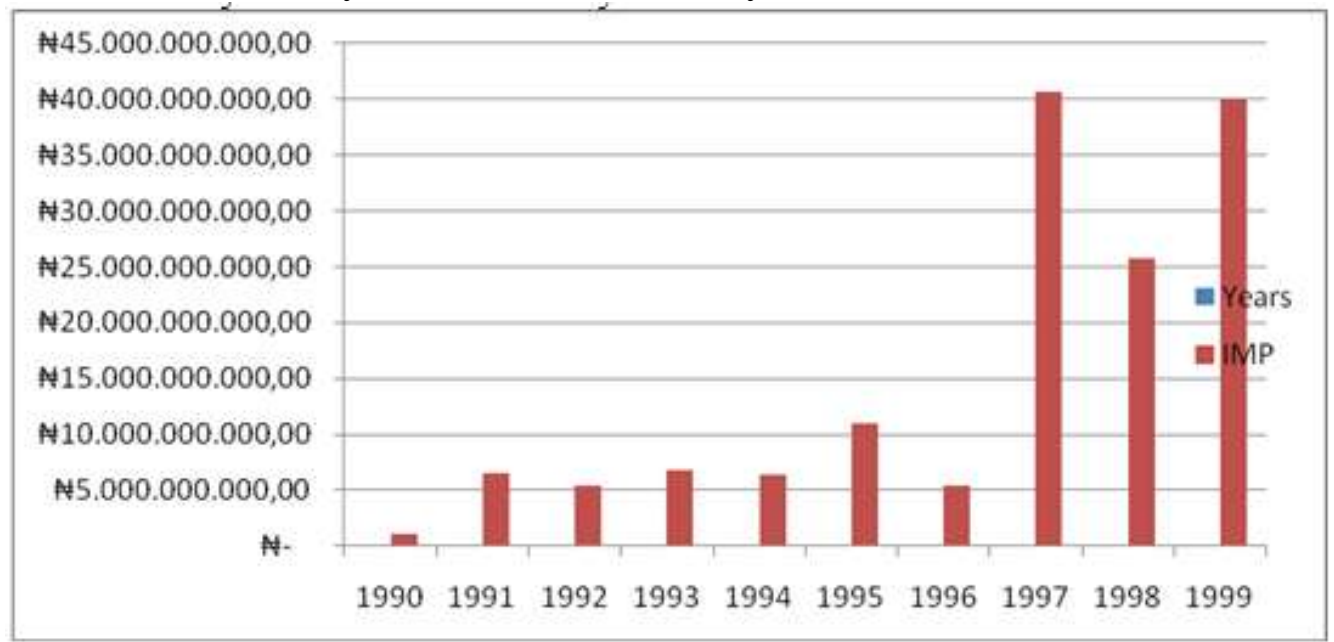

Figure 4. Import from China to Nigeria (1990-1999)

Source: output from Excel, 2019

The above figure shows that the 1990 import of Chinese products to Nigeria recorded a very little rate of $1,030,633,000$ but in 1991 there was very little increase in the import of goods to Nigeria at $\$ 6,593,020,000$. It was in 1992 that China had a drop in imports from Nigeria but eventually increase a very little rate in 1993. The 1994 import of goods from China to Nigeria was dropped at very a little rate of $\$ 6,388,589,751$. In 1995 , the Chinese Government recorded a very moderate import of goods from Nigeria at $\$ 10,989,708,928$ but later dropped to $\$ 5,388,289,053$ in 1996 . However, 1997 recorded a very high increase in import of goods from China to Nigeria at 40,667,431,116 but after this increase in 1997, the Chinese government recorded a decrease at 25,693,468,606 in 1998 but eventually increase again in a moderate form in 1999 at $\$ 39,890,423,259$ when Nigeria had a democratic government. This chart implies that Chinese import to Nigeria is fluctuating within the period listed in the chart.

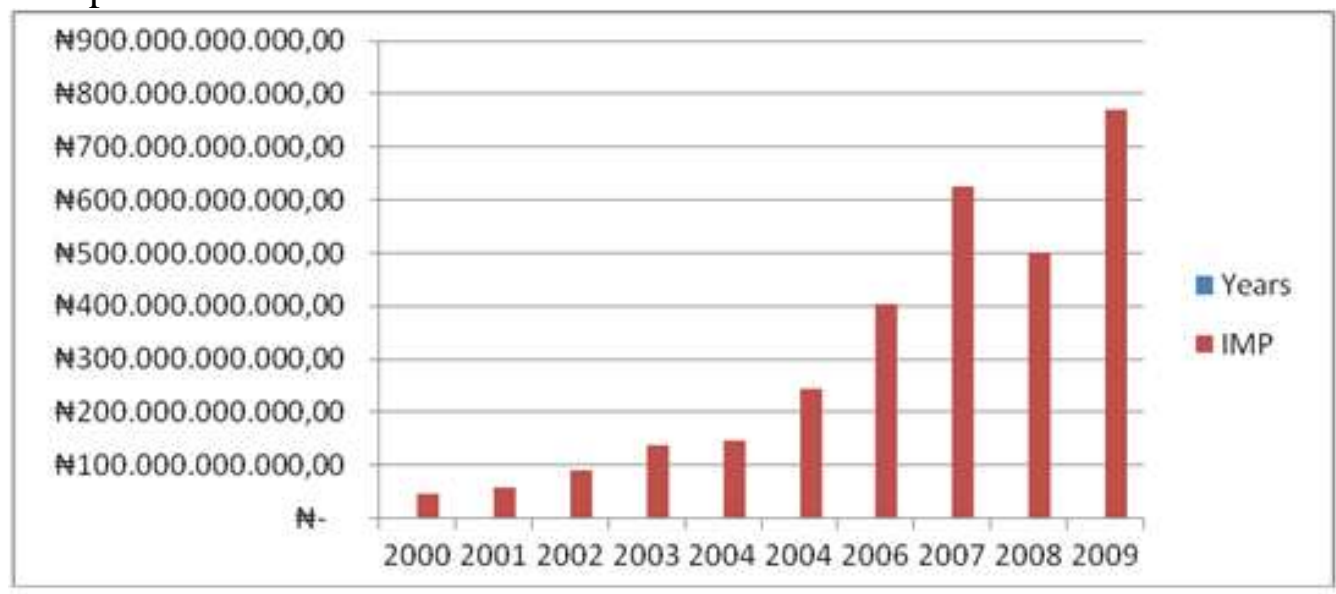

Figure 5. Import from China to Nigeria (2000-2009) 
The above Figure recorded that the import of Chinese products to Nigeria by the Nigerian government was increasing from 2000 to 2007 at an increasing rate. It revealed that Nigeria imports goods from China at an increasing rate and that the rate of increase is by year increase starting from 2000 to 2007. The chart indicated it was only in 2008 that the Nigerian government had a decrease in Chinese products import to Nigeria. However, after 2008, the Chinese government recorded a high increased in their import to Nigeria. This chart implies that the Nigerian Government increased its import of goods from China at an increasing rate each year.

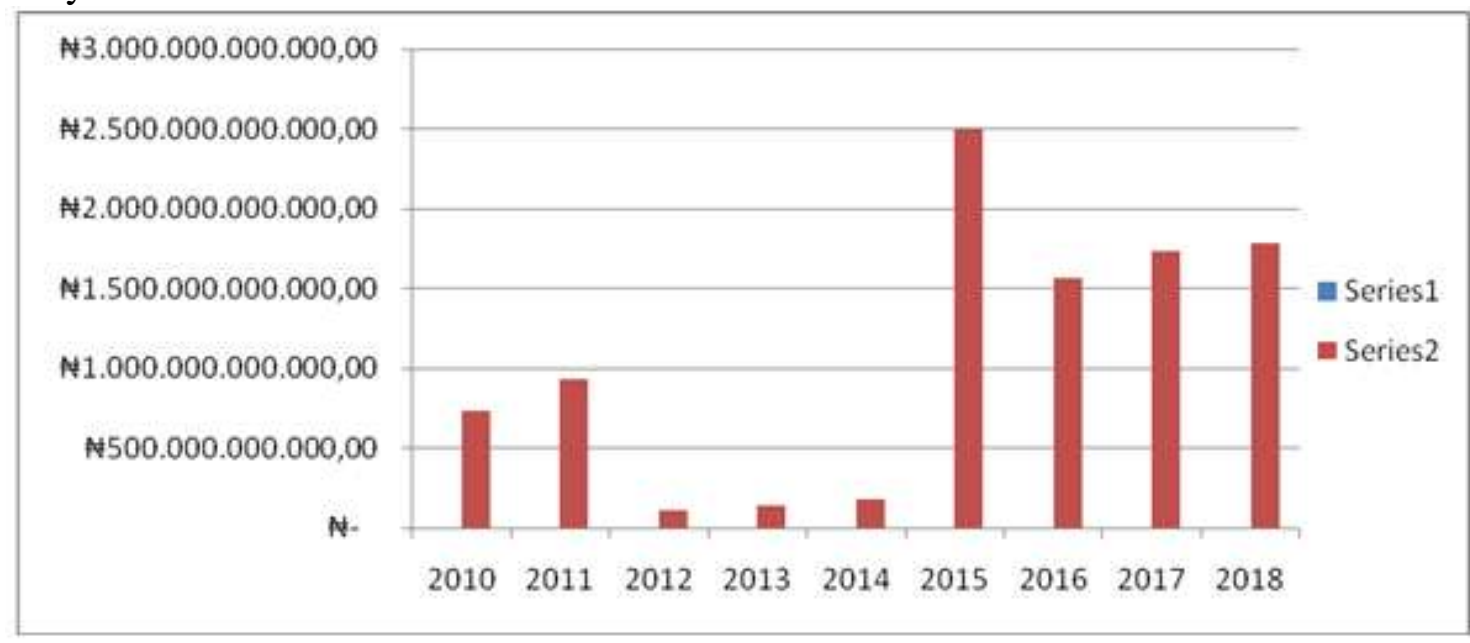

Figure 6. Import from China to Nigeria (2010-2018)

Source: output from Excel, 2019

The figure revealed that 2010 import of goods from China to Nigeria was recorded at \$733,230,841,800 but there was a very little increase in import of goods from China to Nigeria in 2011 at 935,884,344,499 which was an improvement from the previous year. However, 2012, 2013 and 2014 recorded a very little import of goods from China to Nigeria but it was in 2015 that Nigeria imported Chinese products at a very high rate but eventually reduced the importation rate from China to Nigeria in 2016, 2017 and 2018 which may be due to the government ban of some goods. However, the reduction of importation of Chinese products is moderate and can also favour the Chinese government compared to 2012, 2013 and 2014 importation rate in China. The implication of this is that there is a moderate increase in the importation of Chinese products to Nigeria.

Table 1. T-Test

One-Sample Statistics

\begin{tabular}{|l|l|r|r|r|}
\hline & N & \multicolumn{1}{c|}{ Mean } & \multicolumn{1}{c|}{ Std. Deviation } & \multicolumn{1}{c|}{ Std. Error Mean } \\
\hline EP & 29 & 350395741859.45 & 1688639263453.053 & 313572439085.962 \\
IMP & 29 & 443452477769.69 & 659441128458.118 & 122455143356.887 \\
\hline
\end{tabular}

One-Sample Test

\begin{tabular}{|c|c|c|c|c|c|c|}
\hline & \multicolumn{6}{|c|}{ Test Value $=0$} \\
\hline & \multirow[t]{2}{*}{$\mathbf{t}$} & \multirow[t]{2}{*}{ Df } & \multirow[t]{2}{*}{$\begin{array}{c}\text { Sig. } \\
(2 \text {-tailed })\end{array}$} & \multirow[t]{2}{*}{$\begin{array}{c}\text { Mean } \\
\text { Difference }\end{array}$} & \multicolumn{2}{|c|}{$\begin{array}{l}\text { 95\% Confidence Interval of the } \\
\text { Difference }\end{array}$} \\
\hline & & & & & Lower & Upper \\
\hline$\overline{\mathrm{EP}}$ & 1.117 & 28 & .273 & 350395741859.448 & -291928281834.33 & 992719765553.23 \\
\hline IMP & 3.621 & 28 & .001 & 443452477769.690 & 192614487567.90 & 694290467971.47 \\
\hline
\end{tabular}

Source: SPSS Version 20.00, 2019 
The table below indicates the export from Nigeria to China is insignificant in Nigeria since the probability value is more than $1 \%, 5 \%$ and $10 \%$. This implies that Nigeria's government engagement in trade relations is not beneficial to the nations since the Nigerian government only exported limited goods to China such as oil and gas, ores, seeds, fruits, elegiac, woods, skins, leads, etc. However, the study revealed that since 1990 that Nigeria export goods to China till 2018, the country has not recorded in gain from engaging in trade relations with China. The reason is that the Nigerian government imports virtually everything from China but export very little for them.

The table also showed that import from China to Nigeria is significant to China since the Chinese government produced and manufactured virtually that Nigerian needs to use and import into Nigeria at an affordable rate. The reason also is that China has entered into producing industrial and chemical goods which Nigeria had not produced as well as the manufacturing of cars and laptops. From this, China gains from trading with Nigeria.

If the mean values are compared, it is also discovered that China gain from trading with Nigeria. Also, when the standard deviation is compared, China gains from importing their goods to Nigeria and when t-test values are compared from the table, China gains from trading in Nigeria than Nigeria.

Table 2. Trade Balances (1990-2018)

\begin{tabular}{|c|c|c|c|c|c|c|}
\hline $\begin{array}{l}\text { Ye- } \\
\text { ars }\end{array}$ & Export & Import & $\begin{array}{c}\text { Ga- } \\
\text { in } \\
\text { (Ni } \\
\text { ge- } \\
\text { ria) }\end{array}$ & Loss (Nigeria) & Gain (China) & $\begin{array}{c}\text { Los } \\
\text { s } \\
(\mathbf{C h} \\
\text { ina })\end{array}$ \\
\hline & N'000 & N'000 & $\begin{array}{l}\text { N'0 } \\
00\end{array}$ & N'000 & N'000 & $\begin{array}{l}\text { '’0 } \\
00\end{array}$ \\
\hline 1990 & $44,870,000.00$ & $1,030,633,0000$ & & $58,193,300$ & $58,193,300$ & \\
\hline 1991 & $21,073,000$ & $6,593,020,000$ & & $6,571,947,000$ & $6,571,947,000$ & \\
\hline 1992 & $24,619,341$ & $5,448,585,779$ & & $5,423,966,438$ & $5,423,966,438$ & \\
\hline 1993 & $34,526,774$ & $6,765,767,864$ & & $6,731,241,090$ & $6,731,241,090$ & \\
\hline 1994 & $31,676,758$ & $6,388,589,751$ & & $6,356,612,993$ & $6,356,612,993$ & \\
\hline 1995 & $325,329,674$ & $10,989,708,928$ & & $10,664,379,254$ & $10,664,379,254$ & \\
\hline 1996 & $39,360,000$ & $5,388,289,053$ & & $5,348,929,053$ & $5,348,929,053$ & \\
\hline 1997 & $12,671,356,489$ & $40,667,431,116$ & & $27,996,074,627$ & $27,996,074,627$ & \\
\hline 1998 & $14,125,595,743$ & $25,693,468,606$ & & $101,452,292,140$ & $101,452,292,140$ & \\
\hline 1999 & $10,671,356,489$ & $39,890,423,259$ & & $29,219,066,770$ & $29,219,066,770$ & \\
\hline 2000 & $11,413,354,432$ & $46,367,894,115$ & & $34,954,539,683$ & $34,954,539,683$ & \\
\hline 2001 & $14,127,160,262$ & $58,595,546,570$ & & $44,468,386,308$ & $44,468,386,308$ & \\
\hline 2002 & $8,812,297,309$ & $89,138,079,432$ & & $80,325,782,123$ & $80,325,782,123$ & \\
\hline 2003 & $15,954,209,434$ & $137,917,168,694$ & & $121,961,959,260$ & $121,961,959,260$ & \\
\hline 2004 & $70,531,578,270$ & $147,913,615,216$ & & $77,382,036,946$ & $77,382,036,946$ & \\
\hline 2005 & $46,742,407,524$ & $244,653,672,626$ & & $197,911,265,102$ & $197,911,265,102$ & \\
\hline 2006 & $527,401,740$ & $403,319,768,287$ & & $402,792,366,547$ & $402,792,366,547$ & \\
\hline 2007 & $11,136,551,552$ & $626,687,597,642$ & & $61,551,046,090$ & $61,551,046,090$ & \\
\hline 2008 & $31,353,471,339$ & $502,302,250,348$ & & $470,948,779,009$ & $470,948,779,009$ & \\
\hline 2009 & $83,472,435,000$ & $771,236,402,401$ & & $687,763,967,401$ & $687,763,967,401$ & \\
\hline 2010 & $10,804,260,000$ & $733,230,841,800$ & & $722,426,084,499$ & $722,426,084,499$ & \\
\hline 2011 & $1,706,576,000$ & $935,884,344,499$ & & $934,177,768,499$ & $934,177,768,499$ & \\
\hline 2012 & $1,674,434,000$ & $109,896,883,800$ & & $108,222,449,800.00$ & $108,222,449,800.00$ & \\
\hline 2013 & $1,537,958$ & $137,416,062,701$ & & $13,414,524,743$ & $13,414,524,743$ & \\
\hline 2014 & $2,345,535$ & $183,611,745,100$ & & $183,609,399,565$ & $183,609,399,565$ & \\
\hline 2015 & $157,485,113,315.90$ & $2,494,420,661,881.66$ & & $2,336,935,548,565.76$ & $2,336,935,548,565.76$ & \\
\hline 2016 & $9,122,138,909,076.15$ & $11,567,686,056,253$. & & $24,455,471,476.85$ & $24,455,471,476.85$ & \\
\hline 2017 & $220,569,168,578.98$ & $1,734,437,405,377.50$ & & $1,513,868,236,798.52$ & $1,513,868,236,798.52$ & \\
\hline 2018 & $315,033,538,329.91$ & $1,786,549,941,221.19$ & & $1,471,516,402,891.28$ & $1,471,516,402,891.28$ & \\
\hline
\end{tabular}


From the above table, it indicates that export from Nigeria to China is lost to Nigeria sine Nigeria import almost everything from Chinese Government without manufacturing any industrial goods and computers accessories. From 1990 to 2018, the engagement of Nigeria to China in trade relations became lost to Nigeria but gain to China. However, the Chinese Government benefited from transacting international business with Nigeria. The gain from the trade is that Chinese manufacturing almost everything and ensured that the cost is affordable for the poor and the rich to be able to purchase the products. The lost is that Nigerian hardly produced goods apart from the export of oil and gas to China. Nigerian government engagement in trade relations to the Chinese government is not beneficial to Nigeria since the Nigerian Government does not have any unique industrial goods that they produced to exchange with the Chinese government apart from the oil and gas.

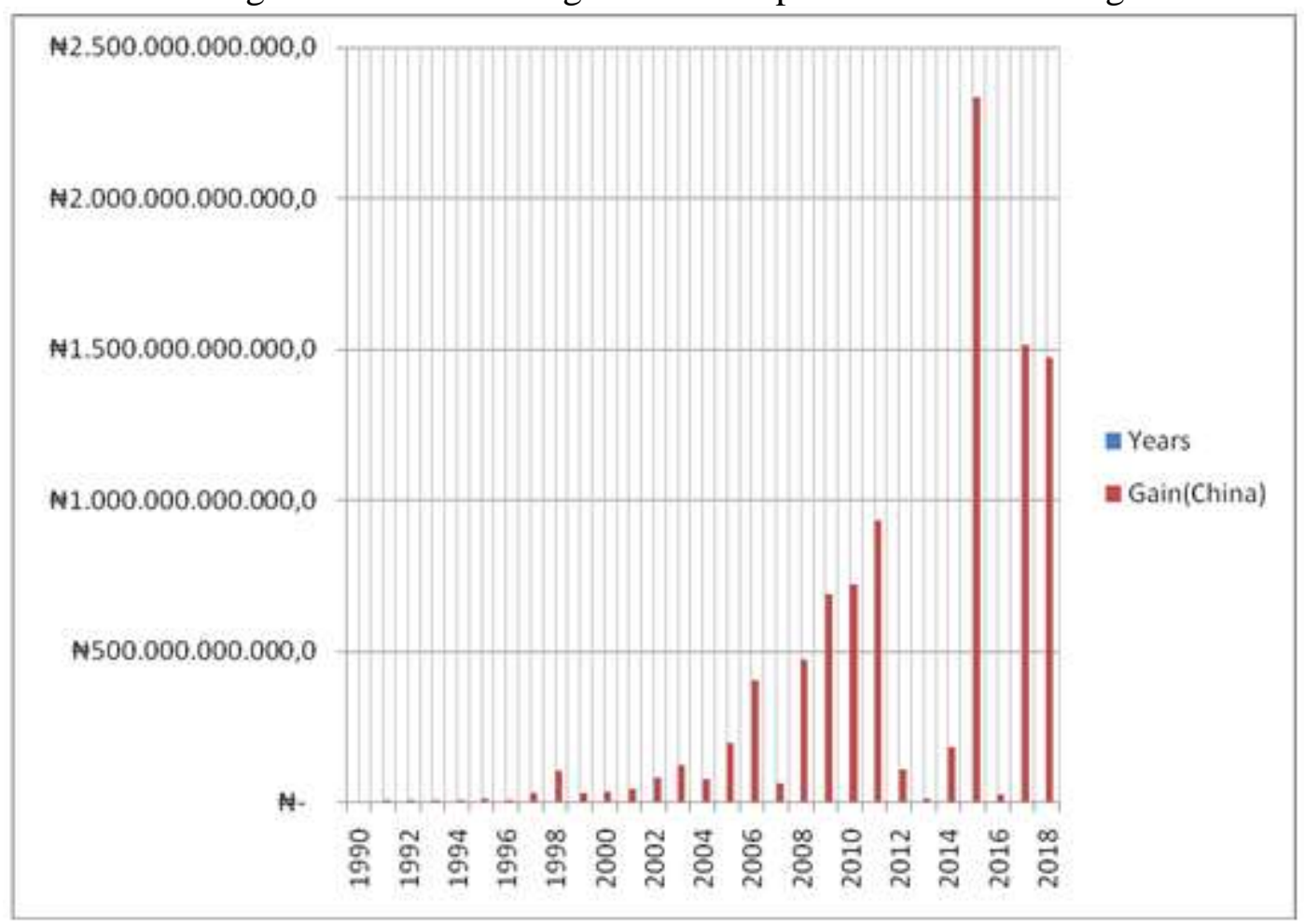

Figure 7. Import from China to Nigeria (1990-2018) Source: output from Excel, 2019

The above figure also showed that China benefited from engaging in trade relations in Nigeria starting from 1990 to 2018. It is only China that benefited from trade relations in Nigeria because they manufactured virtually everything like computers, laptops, machinery, nuclear reactors, boilers, electrical equipment, electronic equipment, vehicles, iron, steel, chemical products, organic products, rubbers, plastics, optical, photo, papers, medical apparatus, articles of iron and steel, lap equipment, phones and its parts, generator, water refilled etc. From the figure, China started the benefit from trading in Nigeria in 1990 at $58,193,300$ and from there, they recorded an increase in benefiting from Nigeria China trade relation. However, the benefit is fluctuating which implies that some years that recorded higher while the other years they recorded lower.

\section{DISCUSSION OF FINDINGS}

The study found that the Nigerian government entered into trade relations with the Chinese Government from 1990 to 2018. It is found that Nigeria had not gained from trade relations 
with China since 1990 to 2018. The study found that it is only China that benefited from trade relations with Nigeria since 1990 to 2018. The reason is that China manufactured industrial goods such as steel, iron, manufacturing plants, printing equipment, laptops etc which the Nigerian government does not manufacture or produced. It is also noted that China benefited from trade relations with Nigeria since 1990 because of medical equipment they produced that Nigeria cannot produce such as diagnostic equipment, treatment equipment, life sports equipment, durable medical equipment and medical laboratory equipment etc. China also benefited from trade relations with Nigeria because they produced papers that we used every day in the offices and workplaces. Nigerian government lost from engaging in trade relations because they lack manufacturing ability and skills, they only exported their natural resources and agricultural products to China and these agricultural products are very limited and very little.

\section{CONCLUSION AND RECOMMENDATION}

The study concluded that Nigeria has not benefited from trade relations with China from 1990 to 2018. It is only China that benefited from trade relations with Nigeria since 1990 to 2018. It is also realized that the Nigeria government have not produced any manufacturing or industrial good that they can exchange with the Chinese government throughout the reviewed period. Nigeria imported virtually everything from China (manufacturing products, industrial products, and medical equipment as well as printing equipment).

The study recommended that Nigerian Government should re-strategize its industrial sector to enable them manufacturing industrial goods and manufacturing goods as well as medical equipment to export to China. They should try to discover what type of industrial goods that China does not well produce and should re-strategise to produce it with low labour and low capital. Nigerian government should try to ensure that they should benefit from engaging in trade relations with China but if eventually they cannot meet-up with the fastgrowing China economy, they should import less from them and try to develop by ensuring that local manufacturing industries are financed to produce locally and consumed.

The Chinese Government should continue to import goods to Nigeria since they are the ones benefiting from trade relations in Nigeria from 1990 to 2018. They should also encourage the Nigerian government to produce and manufacturing industrial goods so that they can face a little competitive with Nigeria in the future for improvement of their products.

\section{REFERENCES}

Mthembu-Salter, G. (2010). Elephants, ants and superpowers: Nigeria's relations with China. China in Africa Project. South African Institute of International Affairs. Occasional Paper, No.42. [Online]. Available: http:// www.saiia.org.za/doc_view/105elephants-ants-and-superpowers-Nigeria-relations-with-china

Obiorah, N. (2006). From China with love, trade and guns: A human rights perspective on China and Africa, in L. Wild and D. Mepham (eds). The new Sinosphere: China in Africa. London: Institute for Public Policy Research. 47 -53.

Ogunsanwo, A. (2008). A tale of two giants, in K. Ampiah and S. Naidu (eds.). Crouching Tiger, Hidden Dragon?: Africa and China. Durban: University of KwaZulu-Natal Press. 192-207.

Umejei, E. (2009). Nig Comsat 1: Re-inventing the Satellite Controversy. Emeka Umejei's Blog [Web log post].https://emekaumejei.wordpress.com/2009/01/04/nigcomsat-1reinventing thesatellite-controversy/ [2019, August 14].

Taylor, I. (2007). China's relations with Nigeria. The Commonwealth Journal of International Affairs: The Round Table, 96(392): 631-645. 